\title{
Professional Qualification Scale for Pre-service Teachers ${ }^{1}$
}

\author{
Assoc. Prof. Dr. Pinar YeNGin SARPKAYA \\ Aydin Adnan Menderes University-Turkey \\ pinar@sarpkaya.net
}

\author{
Res. Assit. Burcu ALTUN \\ Aydin Adnan Menderes University-Turkey \\ burcu.altun@adu.edu.tr
}

\begin{abstract}
:
Teacher education is an important component of the education system and aims to improve the teaching skills of prospective teachers. The teaching skills of pre-service teachers are closely related to their professional qualifications. The present study attempts to develop a valid, reliable, multidimensional measurement tool for assessing the perceptions of pre-service teachers about their professional qualifications. The study was designed in survey model and 247 pre-service teachers participated in the study. Exploratory and confirmatory factor analysis were performed for data analysis. Research results reveal that the developed "Professional Qualification Scale for Pre-service Teachers" is a valid and reliable tool with 0,94 Cronbach alpha value to measure the perception of the pre-service teachers about their competencies. It examines teacher qualifications under 6 dimensions as: Following and Assessing Teaching and Development, Program and Content Knowledge, Personal and Professional Values, School-Family Relations, Professional Development and School

Environment.
\end{abstract}

Key words: Pre-service teacher, quality, professional development

self-efficacy, scale.

Received: 12.06 .2020

Accepted: 12.02 .2021

\section{Suggested Citation:}

Yengin Sarpkaya, P. \& Altun, B. (2021). Professional Qualification Scale for Pre-service Teachers, E-Uluslararası Eğitim Araştırmaları Dergisi, Cilt: 12, Sayl: 1, 2021, ss. 104-123, DOI: 10.19160/ijer.836733

\footnotetext{
${ }^{1}$ A part of this study presented as a proceeding at "International Symposium of New Issues in Teacher Education (2016)".
} 


\section{INTRODUCTION}

Education is of great importance in the welfare of countries. Specifically, teacher education is the key factor for educational development. In order to reach at the objectives of teacher education, it is required to evaluate the quality of educational system and to improve policies accordingly. Research studies targeting the measurement and assessment of teacher quality and quality of teacher education are vital to the sustainable development. Moreover, in order to assess the quality of the teacher education, it is essential to analyze the system itself.

\section{Teachers' Role in Students' Learning and Teacher Qualifications}

Teachers are one of the main components for students' learning to many education specialists. Especially teacher qualification and competence are key factors for improving students' learning (Levin, 2003) and academic success (Buddin and Zamarro, 2009). Education researches, convincingly, states that the most substantial factor influencing the student success is the quality of teacher (Goldhaber, 2006). Teachers getting a better education perform more sensitive, responsive and positive interactions with children, ensure vast language and cognitive experience with children, and show less authoritarian, punitive and indifferent attitudes (Barnett, 2003). So, the quality for education seems to be parallel with teacher quality in many situations (Celep, 2009).

The definition of teacher qualification may vary from culture to culture. It may change with respect to needs of society. Many research studies address the gap between teacher qualifications even in one country (Boyd, Lankford, Loeb, Rockoff and Wyckoff, 2008). On the other hand, many of them define teacher qualifications in their research context.

The literature review done by Rice (2003) summarizes five teacher characteristics reflecting quality of teachers. These are (1) experience of teacher, (2) preparation programs and degrees for teachers, (3) teacher certification type, (4) specific courses completed, and (5) self-test scores of teachers. It examines empirical studies evaluating the teacher characteristics over the effectiveness of teachers. All in all, many studies (Toprakçı, 2001; Toprakçı, 2003; Toprakçı \& Üstün, 2003; Aktağ \& Walter, 2005; Yiğit \& Alev, 2007; ilğan, 2013; Arcagök, Demir \& Şahin, 2015; Baş \& Şentürk, 2019; Güven, 2020) share a common finding that teacher experience has positive effects on the effectiveness of teacher. Moreover, institutional prestige of the teacher positively effects the student achievement. Courses completed in the subject specific area and pedagogy positively contribute to outcomes of learning and teaching. Coursework taken for pedagogical purposes seem to add at all of the grade levels up to effectiveness of teacher. High student achievement seems to be related with the tests evaluating literacy levels or verbal abilities of teachers. It can be summarized being an expert in both subject area and pedagogy is crucial for achieving desired learning outcomes.

Cannor, Son, Hindman and Morrison (2005) examine three classroom practices of teacher as warmth/responsivity, control/discipline, and time spent on academic activities that are related to some skills of children in relation to teachers' elementary education certificate, years of education and years of experience. Also, they examine the effect of this core system embedded in a larger system including children's vocabulary and word recognition skills prior to school entry, their home and pre-school learning environments, and family socio-economic status. Results demonstrated students whose teachers were warmer and more responsive and who spent more time in academic activities performed stronger vocabulary and decoding skills at the end of the first grade. Teachers with more years of education interacted with students more responsively but, surprisingly, their students had weaker early reading skills.

Buddin and Zammaro (2009) say teacher quality is a key component of students' academic success, on the other hand classroom outcomes are influenced by few specific teacher characteristics. Their research aims to determine the effect of teacher licensure test scores (a general knowledge, a subject area and a reading pedagogy tests) and other teacher attributes on student achievement. Longitudinal student-level data were used in the research. Results reveal that there are huge differences in teacher quality across the school district, but there is no relationship between teacher licensure test scores and teacher success in the classroom. Student 
achievement increases with teacher experience, but the relationship is weak and largely reflects poor outcomes for teachers during their first or second year. All in all, teacher qualifications are defined variously but quality of license program, experience, teacher selection method and some other variables as well affect the quality of teachers. In Turkey, teacher qualifications are principally defined by Ministry of National Education (MoNE). These definitions are based on national criteria and contemporary needs of system.

\section{MoNE's Qualification Definition}

Ministry of National Education summarizes teacher qualifications under six dimensions as Personal and Professional Values-Professional Development, Recognizing Student, Teaching and Learning Process, Following and Assessing Teaching and Development, School, Family and Society Relations, Program and Content Knowledge (MoNE, 2006).

Personal and Professional Values-Professional Development dimension consists of qualifications such as valuing students, considering their differences and posing a role model for them. Moreover, attempting continuous development and following legal regulations about teachership are other qualifications of the dimension.

Recognizing Student dimension consists of qualifications about recognizing students all characteristics, interests, needs and knowing characteristics of socio-cultural environment to which they belong.

Teaching and Learning Process dimension consists of qualifications about teacher's all plans, implications and management skills for learning and teaching process.

Following and Assessing Teaching and Development dimension is composed of the qualifications about assessing students in terms of development and learning. Moreover, making students evaluate themselves and peers is another qualification of the dimension.

School, Family and Society Relations dimension consists of qualifications related to knowing school environment characteristics including natural, socio-cultural and economic factors.

Program and Content Knowledge dimension consists of qualifications about field of expertise. Knowing and applying National Education System's basic values, principals and related field's approaches, aims, principals and techniques are qualifications of the dimension (MoNE, 2006). Ministry of National Education expects teachers to demonstrate those qualifications. Moreover, it regulates and guarantees few of the qualifications with the teacher selection exam.

In 2017 teacher qualifications were redefined by MoNE as Professional Knowledge, Professional Skills and Attitudes and Values. Professional knowledge consists of field knowledge, field educational knowledge and legislation of education; professional skills consist of planning the teaching and learning, creating learning mediums, managing the teaching and learning process and measurement and assessment; attitudes and values consist of national, moral and universal values, approaching to students, communication and cooperation, personal and professional development aspects (MoNE, 2017).

In Turkey there is a national central exam for teacher selection. The name of the exam is Public Personnel Selection Examination for Teachers. It is a paper and pencil type exam which is constructed by only multiple-choice questions. The percentages of questions according to subjects were reorganized in 2013 by Turkish Republic Measure, Selection and Placement Center. The exam is held in three sessions. The first one includes general skills and general culture questions, the second includes questions about educational sciences and the third includes subject field related questions (OSYM, 2013). To be a teacher in public schools, the exam is compulsory, on the other hand for the private schools and education centers, it is not compulsory to take this exam; teachership diploma is sufficient. On the other hand, global education market demands highly comprehensive skills from teachers, so each private institution offers different opportunities and expects various skills from the teachers.

Around the world, there is an increasing concern about teacher qualifications. For example, according to Darling-Hammond and Sykes (2003), No Child Left Behind (NCLB) Act 
provides a standard for equal access to teacher quality that is both reasonable and feasible. On the other hand, achieving this goal will require a new vision of the teacher labor market and the framing of a national teacher supply policy. Governments and local administrative bodies have crucial roles in ensuring a supply of highly qualified teachers; however, they are to be supported by proper national programs. NCLB is one of the most discussed education reform effort. One of the many controversial and vexing elements of the law, especially among teachers, teacher unions, and other school officials is the highly qualified teacher provision (Porter-Magee, 2004).

Many research studies address the need for defining and developing teacher skills. Growing body of research results supported the recognition of the concern with teacher quality (Darling-Hammond and Sykes, 2003). Some of these research studies are about measuring the teacher qualifications. There are some scales developed by researchers in order to define, develop and assess teacher qualifications.

\section{Scales for Measuring Teacher Qualifications}

In literature there are limited research studies assessing teacher qualifications. Some research studies address the efficacy of pre-service teachers, some point out their qualification in a specific field such as classroom management. But there is no research addressing their qualification comprehensively in terms of how much they are qualified in specific areas.

Gibson and Dembo (1984) constructed a 30 item Teacher Efficacy Scale to measure teacher efficacy. They also searched the relationship between teacher efficacy and observable teacher behaviors. As a result of analysis of 208 elementary school teacher's data, the scale yielded 2 factors corresponding to Bandura's self-efficacy model. Also, the data from 55 teachers on 3 traits (teacher efficacy, verbal ability, and flexibility) were analyzed. As a result, classroom observations related to academic focus and teacher feedback behaviors indicated differences between 8 high and low efficacy teachers in time spent in class and small group instruction, teacher use of criticism, and teacher persistence in failure.

Guskey and Passaro (1994) examined the structure of teacher efficacy. They used a scale adapted from the research of Gibson and Dembo (1984). 342 pre-service and in-service teachers participated in the research. Contrary to previous research, these factors corresponded to a simpler internal versus external distinction, similar to locus of control measures of causal attribution.

Diken (2004) also analyzed the validity and reliability of Teacher Efficacy Scale in Turkish language for assessing teachers' sense of efficacy. Researcher used the scale developed by Gibson and Dembo (1984) and revised by Guskey and Passaro (1994). 120 Turkish teachers participated in the study working in Ankara. Principal Components Analysis was conducted and as a result Turkish version of the Teacher Efficacy Scale yielded two factors with 0.71 and 0.73 alpha values respectively. The first factor measures personal teaching efficacy or internal factors by 7 items, the second factor measures general teaching efficacy or external factors by 9 items. The alpha value for the total scale is 0.71 . It is concluded that 16 items Turkish version of the Teacher Efficacy Scale is valid and reliable.

Çapa, Çakıroğlu and Sarıkaya (2005) aimed to develop Turkish version of the Teachers' Sense of Efficacy Scale. 628 pre-service teachers from 6 universities in Turkey took part in the study. Factor analysis resulted in 3 dimensions as follows: Efficacy in Student Engagement, Efficacy in Instructional Strategies and Efficacy in Classroom Management each of them consists of 8 items. The alpha values for the dimensions are $.82, .86, .84$ respectively and .93 for the whole scale.

Şeker, Deniz and Görgen (2005) examines prospective teachers' evaluation of themselves, faculty lecturers and mentors in terms of teacher competencies. Teaching Practice Assessment Form of Higher Education Council of Turkey was used as a measurement tool. Researchers conducted the adaptation and factor analysis of the scale. The 33 items scale administered to 172 prospective teachers. As a result, prospective teachers assess themselves, their friends, mentors and faculty lecturers as competent.

Akbulut (2012) developed a valid and reliable scale to measure the competencies of music 
teachers. 105 music teachers working in Ankara and Denizli were administrated 52 items scale and the alpha value for the Music Teachers' Professional Competencies Scale was calculated as .97 .

Kaya, Polat and Karamüftüoğlu (2014) aimed to develop a scale to measure science teachers' self-efficacy towards teaching science. 156 teachers participated in the research study. The results of confirmatory factor analysis revealed that the scale has a 3-dimensional structure as efficacy in subject knowledge $(\alpha=.80)$, efficacy in realizing in-class activities (performance) $(\alpha=.59)$ and efficacy in laboratory knowledge $(\alpha=.87)$.

There is a master thesis using the "Teachers Self-Efficacy Scale" of Schwarzer, Schmitz and Daytner (1999) as "Professional Efficacy Perception Scale" which is also based on Bandura's theory (Gülebağlan, 2003). Davran (2006) also uses a scale to find out the capabilities of teachers. The capabilities in the scale consists of 4 main capability fields which are field knowledge, managing of teaching and learning period, student services and personal and occupational features. However, there is no information about exploratory and confirmatory factor analysis of the scale.

There are many other scale development studies about self-efficacy of teacher candidates and teachers (Tepe, 2011) and many studies about self-efficacy of teacher candidates and teachers (Arseven, 2016); on the other hand, there is limited research on teacher candidates' professional qualifications. Self-efficacy and professional qualifications are different concepts of field of education. Self-efficacy roots from the studies of Bandura (1977) and is about the faith of individual for his or her own ability to plan and manage future situations. Professional qualification is about knowledge and skills that teachers must have to perform their job as expected. Although Ministry of National Education defines comprehensive national criteria for teacher qualifications, there is no research directly addressing it. In current research, expected qualifications are based on MoNE's studies. Since pre-service teachers in Turkey will work under MoNE's regulations, it is necessary to study the national qualification criteria for teachers and teacher candidates. Although qualifications in this research based on MoNE's studies, it also has a universal character and can be used in other cultures since MoNE's studies are based on international literature, in cohesion with EU countries and with contribution of national and international educational experts and academicians (MoNE, 2017). So, comprehensive multidimensional scale development research studies are crucial to improve teacher education system and teachers. It is expected this study may guide the policy makers and practitioners to develop plans for teachers' professional development by determining the qualification of teacher candidates and teachers. Moreover, this research may support the researchers in terms of focusing on the problematic areas of teacher qualifications and help them to identify the areas necessary to work on. Hence forth, the purpose of the research is to develop a valid and reliable multidimensional measurement tool for assessing the perceptions of pre-service teachers about their professional qualifications.

\section{METHODOLOGY}

\section{Research Model}

The research was conducted using survey model in accordance with the purpose of devloloping the "Professional Qualification Scale for Pre-service Teachers". Survey models aim to describe the world around us via people's attitudes, opinions, behaviors or characteristics (Creswell, 2012; Karasar, 2012). The aim is to get generalizable results (Newman and Benz, 1998) by gathering information about people's opinions related to a phenomenon or an event (Lodico, Spaulding and Voegtle, 2006; Scott and Morrison, 2007). To develop a valid and reliable measurement tool for assessing the perceptions of pre-service teachers about their professional qualifications, the best model is descriptive survey model. 


\section{Study Group}

In scale development, there are different criteria for the number of sample (Mundfrom, Shaw and Lu Ke, 2005). Some says number of study group should be five (Bryman and Cramer, 2001; Büyüköztürk, 2012) or ten times (Tabachnick and Fidell, 2007) more of number of items for factor analysis. Some other says number of participants should be at least 100 subjects (Kline, 1994) and some says 200 is fair and 300 is good for a sample size (Comrey and Lee, 1992). In this study the 53 items scale was applied to 290 participants but 247 of the data were included in analysis which is accepted as fair. Also, if there are more than 4 items loading higher than 0.6 in any of the factors, this factor accepted as reliable independently from size of study group (Guadagnoli and Velicer; 1988 cited in Can, 2016). In this current study, all factors carry this assumption.

The study group of the research is determined as teacher candidates registered in Aydin Adnan Menderes University Faculty of Education Pedagogical Formation Certificate Program in 2015-2016 academic years. There are 14 classes in the program each of which consist of approximately 60 students. Each class is thought as clusters and 5 clusters were selected randomly. Data collection instrument was applied to students of those clusters and finally 290 answered survey form were gathered, 247 of them used for analysis. $67,5 \%$ of the participants are female and $32,5 \%$ of them are male. Their departments are social sciences $(32,2 \%)$, life and mathematical sciences $(21,3 \%)$, health sciences $(6,5 \%)$, applied sciences $(18,7 \%)$ and tourism (21,3\%).

\section{Item Construction}

In order to construct data collection instrument, the related literature was reviewed. "Teacher Profession General Qualifications" published by Ministry of National Education of Turkey (MoNE, 2006) was examined. This publication includes 7 comprehensive qualification fields. Personal and Professional Values-Professional Development field consist of 8 subqualification area and in total 73 performance criteria. Recognizing Student field consists of 4 sub-qualification area and in total 24 performance criteria. Teaching and Learning Process field consist of 7 sub-qualification area and in total 57 performance criteria. Following and Assessing Teaching and Development field consists of 4 sub-qualification area and in total 24 performance criteria. School, Family and Society Relations field consists of 5 sub-qualification area and in total 34 performance criteria and finally Program and Content Knowledge field consists of 3 subqualification area and in total 29 performance criteria (MoNE, 2006).

At the beginning of the item construction process, all the fields, sub-areas and performance criteria were analyzed. Some overlapping criteria were eliminated and 49 items were constructed. After gathering the opinions of two field experts, four more items were added to the item pool. At the end, the survey form was constructed by 53 items which describes behaviors of teachers related to their profession. Each item was written in the form of sentence that represents only one behavior. 5-point Likert scale was represented for each item in the scale from low to high degree. 1 demonstrates lowest, 5 demonstrates highest value for teacher qualification. There is no reverse coded item in item pool; all of them are positive sentences. Table 1 shows examples for the items and responses for them.

Table 1. Sample items.

\begin{tabular}{|l|l|c|r|r|c|c|}
\hline$\#$ & Subject of Qualification & \multicolumn{4}{|c|}{ Level of Qualification } \\
Low & 1 & 2 & 3 & 4 & 5 \\
\hline $\mathbf{1}$ & Making each of my students to realize that they are valuable. & 1 & 2 & 3 & 4 & 5 \\
\hline $\mathbf{2}$ & Respecting individual differences of my students. & 1 & 2 & 3 & 4 & 5 \\
\hline $\mathbf{3}$ & Considering my students' needs while supporting each of their teaching process. & 1 & 2 \\
\hline
\end{tabular}

\section{Content and Appearance Validity of the Instrument}

One of the main advantages of quantitative research is to have the chance of getting valid results (VanderStoep and Johnson, 2009). For the validity of research, it is important to construct it on a theoretically strong base (Neuman, 2007). In this research some preparations were done to satisfy validity of the measurement tool. Content validity and face validity are the main 
concerns of the researchers. The scale was developed based on the teacher qualification criteria of MoNE. The theoretical background of the scale is based on comprehensive content developed by MoNE. Moreover, two field experts examined the scale and agreed upon the items. So, the content validity of the scale is guaranteed. For the face validity of the scale, the introduction part was added which introduces the aim and researchers and gives instructions for answering the questions. Moreover, the structure and style were designed in a way that participants could easily read the items and distinguish each item easily to prevent confusions.

\section{Data Analysis}

The data analyzed by SPSS 21. First of all, 9 cases were eliminated since they were answered systematically. Then other extreme values were determined by Mahalanobis distance and 34 other cases were removed from the data set. Totally 43 cases were eliminated and 247 cases were used for the analysis.

In this scale development research, exploratory (EFA) and confirmatory (CFA) factor analysis techniques were used in order to construct valid and reliable measurement tool. KaiserMeyer-Olkin (KMO) adequacy value and Bartlett's test result were used in order to determine if the data were appropriate for factor analysis as mentioned by Büyüköztürk (2012). As an extraction method, principal component analysis is used and as a rotation method Varimax with Kaiser Normalization is used in order to determine the factor loads and number of factors.

Factor analysis is a multivariate technique to assess the dimensionality of a set of variables (Green and Salkind, 2004). Factor load is a kind of relationship which shows item's correlation with the dimension it belongs to (Can, 2013). The strength of this relationship is included in the respective factor loading (DeCoster, 1988). In general, it is expected for an item to have a factor load more than 0.30 in order to measure a structure. 0.45 is accepted as a good level for factor loads (Büyüköztürk, 2012). Moreover, some indices of EFA are used to decide about the valid structure of the scale which are root mean square error of approximation (RMSEA), normed fit index (NFI), comparative fit index (CFI), goodness of fit index (GFI), adjusted goodness of fit index (AGFI) and standardized root mean square residual (SRMR).

\section{FINDINGS}

\section{Findings Related to Validity of the Professional Qualification Scale for Pre-service Teachers}

Factor analysis was performed to determine the construct validity of the scale and factor loads of the items to assign them into dimensions. Priorly to determine whether the data is appropriate for factor analysis Kaiser-Meyer-Olkin (KMO) adequacy value and Bartlett's test result were used. $\mathrm{KMO}$ is expected to be higher than 0.60 to the relevance of the data for factor analysis and the significance of the calculated chi-square shows the relevance of the data matrix (Büyüköztürk, 2012). The Kaiser Meyer Olkin (KMO) value is .92 and Bartlett's Test of Sphericity $\left(x^{2}=4026.780, d f=378 . p=.000\right)$ is significant which indicates that data set is perfectly suitable for factor analysis and significant. The KMO and Barlett's test results are shown in Table 2.

Table 2. KMO \& Barlett's test results of professional qualification scale for pre-service teachers

\begin{tabular}{lll}
\hline Kaiser-Meyer-Olkin (KMO) adequacy value & & 0.920 \\
\hline \multirow{3}{*}{ Bartlett's Test of Sphericity } & Chi-square value & 4026.780 \\
& $\mathrm{df}$ & 378 \\
& $\mathrm{p}$ & .000 \\
\hline
\end{tabular}

As it is decided the data displays perfect fit for factor analysis, as an extraction method, principal component analysis is used and as a rotation method Varimax from vertical rotation methods is used in order to determine the factor loads and number of factors. Since rotation of the axis increases the load of items over a factor while decreases them over other irrelevant factor it helps to interpret the factors easier (Büyüköztürk, 2012). During the analysis, items which have a factor load lower than 0.30 were eliminated which refers to 25 items. The rest of 
the items have factor loads fluctuates between 0,586 and 0,811 . These levels are higher than the suggested level 0.450 . Table 3 shows the factor loads of 28 items, their factors and explained variances which refer to exploratory factor analysis results of the scale.

It is seen that 28 items are collected under 6 dimensions and all the items in scale acquired high load factors. The percentages of explained variances are as follows: $15,089 \%$ for the $1^{\text {st }}$ factor, $11,659 \%$ for the $2^{\text {nd }}$ factor, $11,415 \%$ for the $3^{\text {rd }}$ factor, $11,193 \%$ for the $4^{\text {th }}$ factor, $9,589 \%$ for the $5^{\text {th }}$ factor and $7,843 \%$ for the $6^{\text {th }}$ factor and $66,789 \%$ in total. For the social sciences the total explained variance between $40 \%$ and $60 \%$ is accepted as sufficient for the social sciences (Tavşancıl, 2005).

It is concluded that the 28 items Professional Qualification Scale for Pre-service Teachers consists of 6 dimensions $(\mathrm{KMO}=.97 ; \mathrm{p}<.000)$, and there is 5 items in the first dimension, 4 items in the second dimension, 7 items in the third dimension, 3 items in the fourth dimension, 4 items in the fifth dimension and 5 items in the sixth dimension. Factor loads of the items in the first dimension fluctuated between .598 and .750 , the ones in the second dimension ranged from .614 to .699 , the ones in the third dimension ranged from .586 to .743 , the ones in the fourth dimension ranged from .680 to .808 , the ones in the fifth dimension ranged from .711 to .742 , the ones in the sixth dimension ranged from .582 to .811 .

Items 1, 2, 3, 4 and 5 are collected under $1^{\text {st }}$ dimension named as "Personal and Professional Values". Items $8,9,10$ and 11 are collected under $2^{\text {nd }}$ dimension named as "Professional Development". Items 31, 32, 33, 35, 36, 37 and 38 are collected under $3^{\text {rd }}$ dimension named as "Following and Assessing Teaching and Development". Items 39, 40 and 41 are collected under $4^{\text {th }}$ dimension named as "School Environment". Items 44, 45, 46 and 47 are collected under $5^{\text {th }}$ dimension named as "School-Family Relations". Finally, Items 49, 50, 51, 52 and 53 are collected under $6^{\text {th }}$ dimension named as "Program and Content Knowledge".

Table 3. Factor loads and factors of professional qualification scale for pre-service teachers

\begin{tabular}{|c|c|c|c|c|c|c|c|}
\hline Name of Factors & Item number & Factor 1 & Factor 2 & Factor 3 & Factor 4 & Factor 5 & Factor 6 \\
\hline \multirow{5}{*}{$\begin{array}{l}\text { Personal and } \\
\text { Professional Values }\end{array}$} & M1 & ,694 & & & & & \\
\hline & M2 &, 743 & & & & & \\
\hline & M3 & ,732 & & & & & \\
\hline & M4 &, 675 & & & & & \\
\hline & M5 &, 586 & & & & & \\
\hline \multirow{4}{*}{$\begin{array}{l}\text { Professional } \\
\text { Development }\end{array}$} & M8 & & ,722 & & & & \\
\hline & M9 & & ,737 & & & & \\
\hline & M10 & & ,742 & & & & \\
\hline & M11 & &, 711 & & & & \\
\hline \multirow{7}{*}{$\begin{array}{l}\text { Following and } \\
\text { Assessing Teaching } \\
\text { and Development }\end{array}$} & M31 & & &, 750 & & & \\
\hline & M32 & & &, 624 & & & \\
\hline & M33 & & &, 598 & & & \\
\hline & M35 & & & 609 & & & \\
\hline & M36 & & & ,611 & & & \\
\hline & M37 & & &, 725 & & & \\
\hline & M38 & & & ,704 & & & \\
\hline \multirow{3}{*}{ School Environment } & M39 & & & & 811 & & \\
\hline & M40 & & & & ,796 & & \\
\hline & M41 & & & &, 582 & & \\
\hline \multirow{4}{*}{$\begin{array}{l}\text { School-Family } \\
\text { Relations }\end{array}$} & M44 & & & & & ,808 & \\
\hline & M45 & & & & & ,828 & \\
\hline & M46 & & & & &, 686 & \\
\hline & M47 & & & & &, 680 & \\
\hline \multirow{5}{*}{$\begin{array}{l}\text { Program and Content } \\
\text { Knowledge }\end{array}$} & M49 & & & & & &, 614 \\
\hline & M50 & & & & & & ,698 \\
\hline & M51 & & & & & & ,699 \\
\hline & M52 & & & & & &, 661 \\
\hline & M53 & & & & & &, 684 \\
\hline Explained Variance & & $15,089 \%$ & $11,659 \%$ & $11,415 \%$ & $11,193 \%$ & $9,589 \%$ & $7,843 \%$ \\
\hline Explained total variance & & $66,789 \%$ & & & & & \\
\hline
\end{tabular}


The validity of the 6-factor structure resulted in exploratory factor analysis was also analyzed by confirmatory factor analysis. The ratio of chi-square value calculated from the 28item form's structural model to its degree of freedom ( $(2 / \mathrm{df})$ was found as 1.7 . The value between 0-2 means perfect fit (Kline, 2005; Hooper, Coughlan and Mullen, 2008). When modification indices were analysed, some modifications were seen to contribute significantly to the model. So, the modifications between error terms 10-11 in factor 2 and 44-45 in factor 5 were performed. The decision about modification is based on the data and theoretical framework as suggested by MacCallum and Austinin (2000). Model fit indices were found as follows: $\mathrm{RMSEA}=.05, \mathrm{NFI}=.86 ; \mathrm{CFI}=.94, \mathrm{GFI}=.87, \mathrm{AGFI}=.84$ and $\mathrm{SRMR}=.06$. Although there is no consensus on what is good fit value among researchers (Tanaka, 1993), some of those fit indices show good model fit (Tabachnick and Fidel, 2015). Based on these results, since the RMSEA value is .05, it shows an acceptable fit (Schumacher and Lomax, 2004; Tabachnick and Fidel, 2015), GFI value is .87 and it is also acceptable fit (Kline, 2005; Seçer, 2013). Also for the value of $\mathrm{CFI}, \mathrm{NFI}$ and AGFI is very close to 1 and it demonstrates an acceptable fit. Schumacher and Lomax (2004) and Kline (2005) suggest those values vary between $0-1.0$ refers to no fit and 1 refers to perfect fit. The more the index value gets closer to 1 , the higher the fit value becomes, so the model indices ensure acceptable fit. So, it is suggested that the scale had acceptable fit on the data of pre-service teachers. Figure 1 demonstrates the structure of the model of "Professional Qualification Scale for Pre-service Teachers."

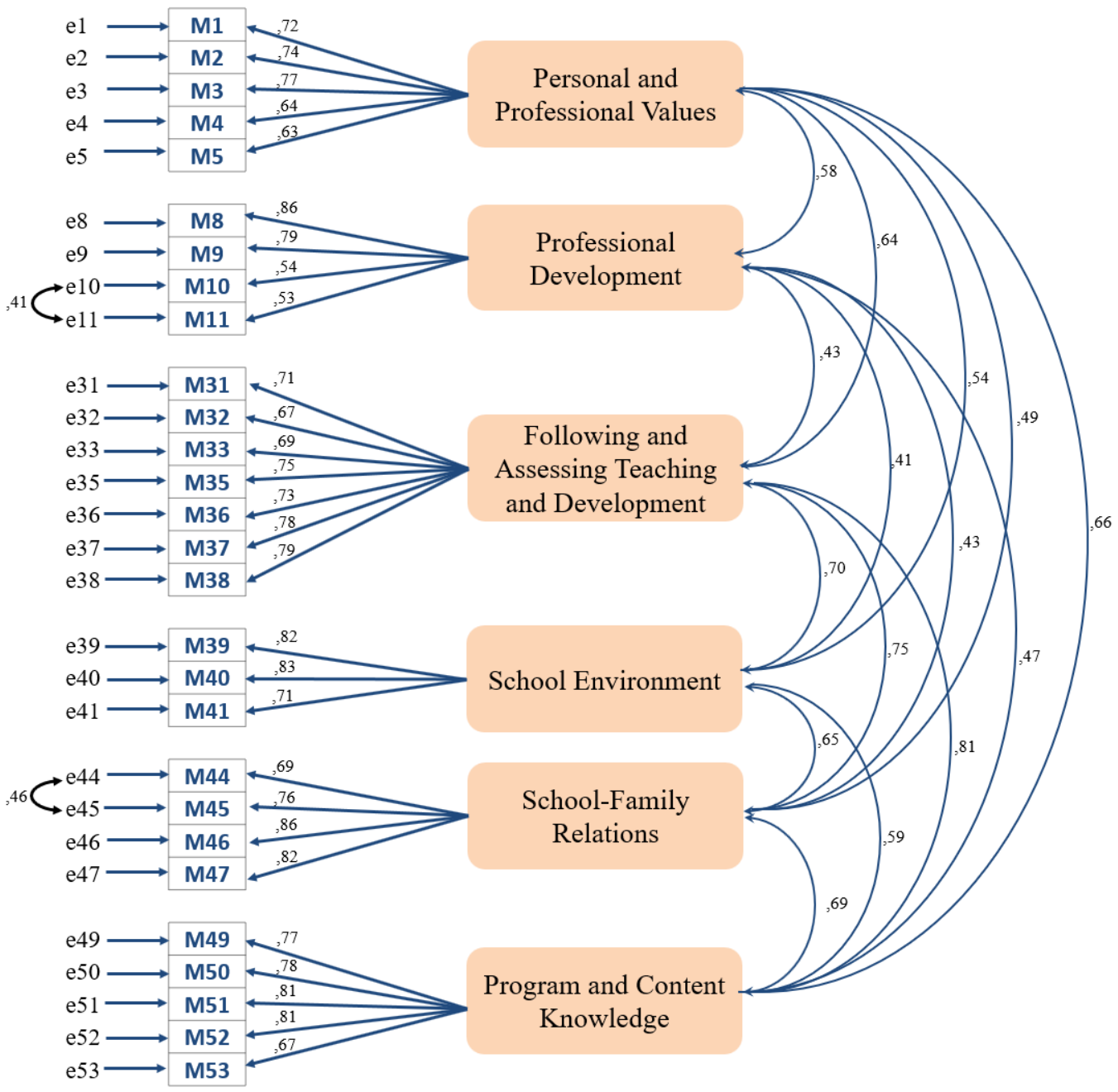

Figure 1. The model of professional qualification scale

$(\mathrm{X} 2=573,04, \mathrm{df}=333 \mathrm{p}<.05 ; \mathrm{RMSEA}=.054, \mathrm{NFI}=.86 ; \mathrm{CFI}=.94$, and $\mathrm{SRMR}=.06$ and $\mathrm{GFI}=.87)$ 
According to model fit indices, it can be concluded that the construct of the "Professional Qualification Scale for Pre-service Teachers" is valid. Factor loads for personal and professional values dimension differs between ,63 and ,72, professional development dimension differs between ,53 and ,86, following and assessing teaching and development dimension differs between ,67 and ,79, school environment dimension differs between ,71 and ,83, school-family relations dimension differs between ,69 and ,82, and program and content knowledge dimension differs between , 67 and , 81 based on the CFA results.

For the validity of the scale the item-factor correlations and correlations between factors and total scale is also important. Item-factor correlations show the relationship of each item with the dimension it belongs and shows the consistency of factor. For each item, the item-factor correlation values are given in Table 4.

Table 4. Item-factor correlations of the scale

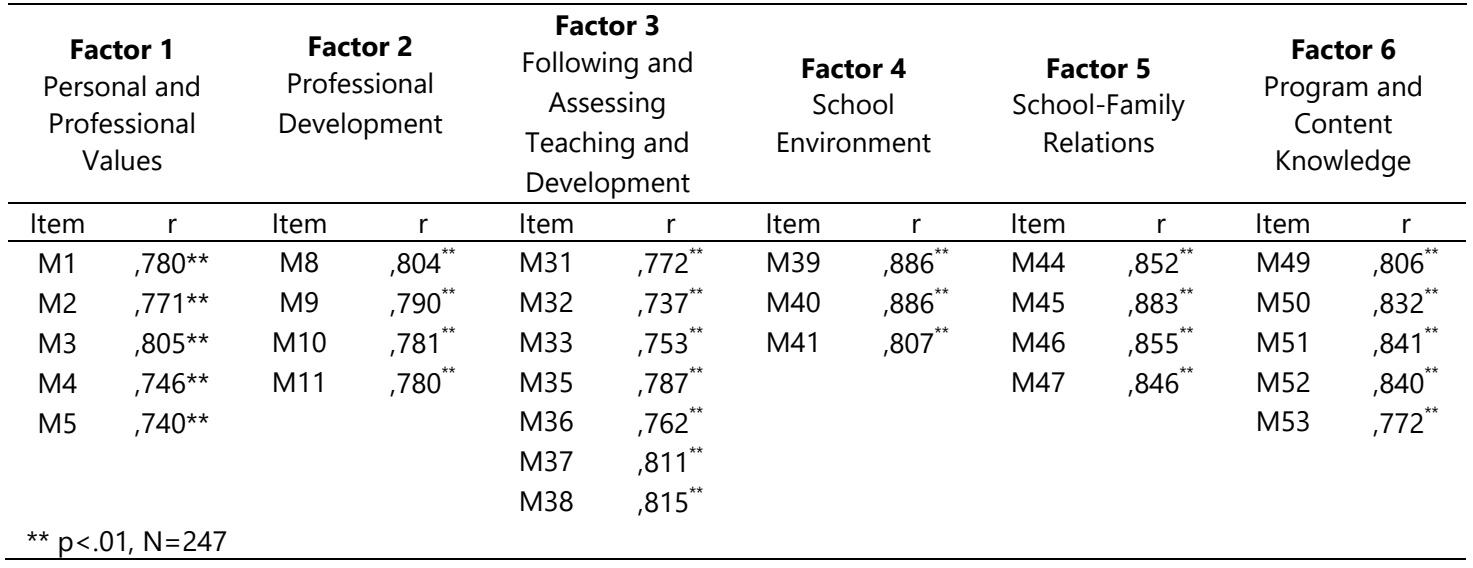

As it is seen in Table 4, correlation coefficients vary between ,740 and ,805 for the $1^{\text {st }}$ factor; , 780 and, 804 for the $2^{\text {nd }}$ factor;, 737 and, 815 for the $3^{\text {rd }}$ factor;, 807 and, 886 for the $4^{\text {th }}$ factor; , 846 and ,883 for the $5^{\text {th }}$ factor and, 772 and ,840 for the $6^{\text {th }}$ factor. Each item of the scale has a significant and positive relationship with the factor it belongs $(p<.01)$. This shows that all items serve to the purpose of the factor it belongs consistently and the level of distinctiveness of each item is quite high. Moreover, the correlations between factors is represented in Table 5.

Table 4. Correlations between factors of the scale and the total scale

\begin{tabular}{lcccccc}
\hline & $\begin{array}{c}\text { Factor 1 } \\
\text { Personal and } \\
\text { Professional } \\
\text { Values }\end{array}$ & $\begin{array}{c}\text { Factor 2 } \\
\text { Professional } \\
\text { Development }\end{array}$ & $\begin{array}{c}\text { Factor 3 } \\
\text { Following and } \\
\text { Assessing } \\
\text { Teaching and } \\
\text { Development }\end{array}$ & $\begin{array}{c}\text { Factor } \mathbf{4} \\
\text { School } \\
\text { Environment }\end{array}$ & $\begin{array}{c}\text { Factor } \mathbf{5} \\
\text { School- } \\
\text { Family } \\
\text { Relations }\end{array}$ & $\begin{array}{c}\text { Factor } \mathbf{6} \\
\text { Program and } \\
\text { Content } \\
\text { Knowledge }\end{array}$ \\
\hline Total scale &, $746^{*}$ &, $645^{*}$ &, $883^{*}$ &, $744^{*}$ &, $776^{*}$ &, $848^{*}$ \\
Factor1 & 1 &, $495^{*}$ &, $561^{*}$ &, $474^{*}$ &, $423^{*}$ &, $559^{*}$ \\
Factor2 & & 1 &, $418^{*}$ &, $385^{*}$ &, $366^{*}$ &, $480^{*}$ \\
$\begin{array}{l}\text { Factor3 } \\
\text { Factor4 }\end{array}$ & & & 1 &, $619^{*}$ &, $644^{*}$ &, $720^{*}$ \\
Factor5 & & & & 1 &, $570^{*}$ &, $536^{*}$ \\
Factor6 & & & & & 1 &, $586^{*}$ \\
${ }^{*} \mathrm{p}<.01, \mathrm{~N}=247$ & & & & & 1 \\
\hline
\end{tabular}

Table 5 shows that the highest correlation is between factor 3 (Following and Assessing Teaching and Development) and factor 6 (Program and Content Knowledge), the lowest correlation is between factor 2 (Professional Development) and factor 5 (School-Family Relations). When the factor-total scale correlations examined it is seen that the highest correlated factor is factor 3 (Following and Assessing Teaching and Development), the lowest correlated factor is factor 2 (Professional Development) with the total scale. It can be concluded 
that all factors are correlated with each other and with the total scale in a significant extent and all the factors are in the same structure.

Another criterion for the item discrimination is the significant difference between item mean scores of the upper and lower $27 \%$ of the participants by total scores. If the item mean scores of the upper and lower $27 \%$ of the participants differ significantly, then it is concluded that the scale discriminates the individuals in terms of measured trait (Büyüköztürk, 2012). The independent samples t-test results of the upper and lower $27 \%$ of the participants is represented in Table 6.

Table 6. Item distinctiveness of the scale based on lower and upper $27 \%$ groups

\begin{tabular}{|c|c|c|c|c|c|c|c|c|c|c|c|}
\hline & Item & $27 \%$ & $\mathbf{x}$ & sd & $\mathbf{t}$ & & Item & $27 \%$ & $\mathbf{x}$ & sd & $\mathbf{t}$ \\
\hline \multirow{10}{*}{ 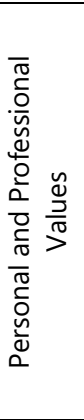 } & \multirow{2}{*}{ M1 } & Upper & 4,75 & ,503 & \multirow{2}{*}{$10,707^{*}$} & \multirow{6}{*}{ 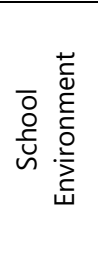 } & \multirow{2}{*}{ M39 } & Upper & 4,57 & ,609 & \multirow{2}{*}{$9,354^{*}$} \\
\hline & & Lower & 3,66 & ,664 & & & & Lower & 3,42 & ,801 & \\
\hline & \multirow{2}{*}{ M2 } & Upper & 4,82 & ,386 & \multirow{2}{*}{$9,482^{*}$} & & \multirow{2}{*}{ M40 } & Upper & 4,60 &, 552 & \multirow{2}{*}{$10,830^{*}$} \\
\hline & & Lower & 3,90 & ,699 & & & & Lower & 3,42 & ,700 & \\
\hline & \multirow{2}{*}{ M3 } & Upper & 4,69 &, 528 & \multirow{2}{*}{$10,523^{*}$} & & \multirow{2}{*}{ M41 } & Upper & 4,57 &, 557 & \multirow{2}{*}{$10,998^{*}$} \\
\hline & & Lower & 3,58 & ,678 & & & & Lower & 3,37 & ,693 & \\
\hline & \multirow{2}{*}{ M4 } & Upper & 4,75 & ,472 & \multirow{2}{*}{$8,256^{*}$} & \multirow{8}{*}{ 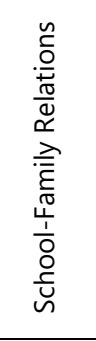 } & \multirow{2}{*}{ M44 } & Upper & 4,51 & ,637 & \multirow{2}{*}{$10,637^{\star}$} \\
\hline & & Lower & 3,90 & ,699 & & & & Lower & 3,25 & ,725 & \\
\hline & \multirow{2}{*}{ M5 } & Upper & 4,81 &, 435 & \multirow{2}{*}{$9,488^{*}$} & & \multirow{2}{*}{ M45 } & Upper & 4,58 & ,607 & \multirow{2}{*}{$10,504^{x}$} \\
\hline & & Lower & 3,75 &, 804 & & & & Lower & 3,22 & ,867 & \\
\hline \multirow{8}{*}{ 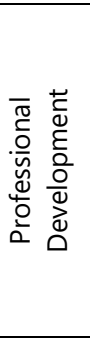 } & \multirow{2}{*}{ M8 } & Upper & 4,61 & ,549 & \multirow{2}{*}{$7,202^{*}$} & & \multirow{2}{*}{ M46 } & Upper & 4,88 & ,327 & $12423 *$ \\
\hline & & Lower & 3,78 & ,775 & & & & Lower & 3,54 & ,823 & $12,4<3$ \\
\hline & M9 & Upper & 4,43 & ,609 & $6.254^{*}$ & & M47 & Upper & 4,66 & ,478 & $12458 *$ \\
\hline & & Lower & 3,70 & ,739 & & & & Lower & 3,24 & ,799 & \\
\hline & M10 & Upper & 4,64 &, 595 & $7682 *$ & & $M 49$ & Upper & 4,88 & 327 & $14150^{*}$ \\
\hline & IVIIO & Lower & 3,75 &, 746 & 1,002 & & $1 \mathrm{~V} 149$ & Lower & 3,63 & ,648 & 14,150 \\
\hline & & Upper & 4,54 & ,636 & & & & Upper & 4,81 & ,398 & \\
\hline & M11 & Lower & 3,63 &, 832 & $1,119^{*}$ & రิ ฮั & Mb0 & Lower & 3,58 & ,655 & $13,0 / 0^{*}$ \\
\hline & M31 & Upper & 4,72 & ,454 & $11286 *$ & $\overline{0}$ & M51 & Upper & 4,81 &, 435 & $11972 *$ \\
\hline & & Lower & 3,54 & ,725 & & $\stackrel{\pi}{\varepsilon} \stackrel{3}{0}$ & & Lower & 3,49 & ,786 & \\
\hline 임 & M32 & Upper & 4,63 & ,517 & 11 372* & $\stackrel{\frac{E}{0}}{\frac{5}{n}}$ & M52 & Upper & 4,82 & ,386 & 13701* \\
\hline & M32 & Lower & 3,42 & ,700 & $11,3 / 3^{x}$ & อ & M52 & Lower & 3,45 & 724 & $13,101^{x}$ \\
\hline$\stackrel{\mathbb{E}}{\mathscr{E}}+$ & M33 & Upper & 4,61 &, 549 & & & & Upper & 4,72 &, 572 & \\
\hline Ю & M33 & Lower & 3,31 & ,743 & $11,505^{\star}$ & & M53 & Lower & 3,54 &, 745 & $10,272^{*}$ \\
\hline 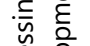 & M35 & Upper & 4,70 & ,461 & $13362 *$ & & & & & & \\
\hline$\stackrel{0}{\tilde{\omega}} \frac{0}{Q}$ & MI35 & Lower & 3,37 & ,671 & $13,362^{n}$ & & & & & & \\
\hline ¿ & M36 & Upper & 4,69 & ,467 & 11139* & & & & & & \\
\hline$\frac{c}{\pi}$ & $\mathrm{M} 136$ & Lower & 3,54 & ,703 & $11,139^{\prime \prime}$ & & & & & & \\
\hline$\stackrel{0}{\leftrightarrows}$ & M37 & Upper & 4,72 &, 454 & $12,257^{*}$ & & & & & & \\
\hline בo & IVIS & Lower & 3,46 & ,703 & $12, \angle 3 / 4$ & & & & & & \\
\hline 인 & M38 & Upper & 4,69 & ,467 & $12162 *$ & & & & & & \\
\hline & IVISO & Lower & 3,28 & ,714 & 13,402 & & & & & & \\
\hline
\end{tabular}

As Table 6 displays, all of the item mean scores differ significantly between upper and lower 27 $\%$ of the participants. So, it is concluded that the distinctiveness of the scale is good $(p<0.001)$.

\section{Findings Related to Reliability of The Professional Qualification Scale for Pre-service Teachers}

In this study, to determine the reliability, Cronbach's alpha coefficients were calculated for each factor and the overall scale. Table 7 shows the reliability coefficients of each factor and the total scale. 
Table 7. Reliability results for total scale and its' factors

\begin{tabular}{lcc}
\hline Name of Factors & Number of items & Cronbach's $\boldsymbol{\alpha}$ \\
\hline Personal and Professional Values & 5 & 0,81 \\
Professional Development & 4 & 0,74 \\
Following and Assessing Teaching and Development & 7 & 0,87 \\
School Environment & 3 & 0,80 \\
School-Family Relations & 4 & 0,86 \\
Program and Content Knowledge & 5 & 0,86 \\
Total scale & 28 & 0,94 \\
\hline
\end{tabular}

As shown in Table 7, Cronbach's alpha reliability coefficient of the 28 items total scale is 0.94 which indicates high reliability. Cronbach' alpha values for each factor are $0.81,0.74,0.87$, $0.80,0.86$ and 0.86 respectively. So, results show that internal consistency of the scale is high enough.

\section{DISCUSION AND CONCLUSION}

The main purpose of this study is to develop a scale that defines valid and reliable measurement tool for assessing the perceptions of pre-service teachers about their professional qualifications. Initially, an item pool was constructed. Then, corrections were made with the help of field experts' opinions and 53 item survey forms was applied to 290 teacher candidates. With Mahalanobis distance calculation and expert opinions, 43 cases were eliminated. Finally, 247 case data used for factor analysis.

According to EFA, principal component analysis and varimax rotation revealed that the scale has 28 items and 6 dimensions. Factor loads for the all dimensions fluctuates between .582 and .811. Explained total variance of the scale is $66,789 \%$. CFA (RMSEA $=.05, \mathrm{NFI}=.86 ; \mathrm{CFI}=.94$, $\mathrm{GFI}=.87, \mathrm{AGFI}=.84$ and $\mathrm{SRMR}=.06$.) also shows that those factors, in other words constructed model demonstrates an acceptable fit which means that the resulted scale is valid. In order to determine the item distinctiveness of the scale both item-factor correlations and difference between item mean scores of the upper and lower $27 \%$ of the participants by total scores were examined. As a result, it is concluded that the distinctiveness of the scale is good. The reliability of the scale is tested by Cronbach's alpha value. The total scale's alpha is 0.94 and the alpha value of dimensions differ between 0.74 and 0.87 which indicates high reliability. The dimensions of the yielded scale and their explanations are given as follows:

- Personal and Professional Values dimension measures the qualification of individual in terms of valuing students, encouraging them and supporting each student individually by 5 items (1-5),

- Professional Development dimension measures the qualification of individual in terms of evaluating his/her own professional development critically by 4 items (6-9),

- Following and Assessing Teaching and Development dimension measures the qualification of individual in terms of following and assessing whether students achieve the objectives or not by 6 items (10-16),

- School Environment dimension measures the qualification of individual in terms of the analyzing and utilizing the environment in which the school operates by 3 items (17-19),

- School-Family Relations dimension measures the qualification of individual in terms of communicating and cooperating with family of students and making them to contribute teaching and learning process by 4 items (20-23),

- Program and Content Knowledge dimension measures the qualification of individual in terms of analyzing the curriculum of his/her field, taking action accordingly and organizing her/his teaching activities accordingly by 5 items (24-28).

The score can be obtained from the scale for each item is minimum 1, maximum 5 since the scale is 5-point Likert scale. The total score can be calculated for both scale and each dimension. 
There are different classifications for teacher qualifications in many studies. According to Rice (2003) teacher experience, teacher preparation programs and degrees, type of teacher certification, specific coursework taken in preparation for the profession, and teachers' own test scores are dimensions of teacher qualification. On the other hand, Cannor et. al (2005) state three dimension of teacher qualification including elementary education certification, years of education, and years of experience on observed classroom practices across three dimensions as warmth/responsivity, control/discipline, and time spent on academic activities. A scale developed by Çapa et. al (2005) measure teacher qualifications as Efficacy in Student Engagement, Instructional Strategies and Classroom Management.

MoNE summarizes teacher qualifications under six dimensions as Personal and Professional Values-Professional Development, Recognizing Student, Teaching and Learning Process, Following and Assessing Teaching and Development, School, Family and Society Relations, Program and Content Knowledge (MoNE, 2006).

This study represents a comprehensive examination of teacher qualifications based on MoNE's studies. According to the findings of the study it can be concluded that "Professional Qualification Scale for Pre-service Teachers" is a valid and reliable tool to measure the perception of the pre-service teachers about their quality with its 6 dimensions as: Following and Assessing Teaching and Development, Program and Content Knowledge, Personal and Professional Values, School-Family Relations, Professional Development and School Environment. The scale form represented in appendix.

\section{REFERENCES}

Akbulut, E. (2012). Müzik öğretmenleri mesleki yeterlikleri ölçeği çalışması (Music teacher's professional competences scale study). Fine Arts, 7(4), 334-346.

Aktağ, I., \& Walter, J. (2005). Öğretmen adaylarinin mesleki yeterlilik duygusu. Spormetre Beden Eğitimi ve Spor Bilimleri Dergisi, 3(4), 127-132.

Arseven, A. (2016). Öz yeterlilik: Bir kavram analizi (Self-efficacy: A concept analysis). Turkish Studies, 11(19), 63-80. http://dx.doi.org/10.7827/TurkishStudies.10001.

Arcagök, S, Demir, M , Şahin, Ç . (2015). Sınıf Öğretmeni Adaylarının Okul Deneyimi Derslerine Ilişkin Tutumlarının Değerlendirilmesi. Dicle Üniversitesi Ziya Gökalp Eğitim Fakültesi Dergisi, (25) , 136-156 . Retrieved from https://dergipark.org.tr/en/pub/zgefd/issue/47936/606387

Bandura, A. (1977). Self-efficacy: Toward a unifying theory of behavioral change. Psychological Review, 84(2), 191-215. https://doi.org/10.1037/0033-295X.84.2.191.

Barnett, W. S. (2003). Better Teachers, better preschools: Student achievement linked to teacher qualifications. National Institute for Early Education Research, 2, 2-12.

Baş, G., \& Şentürk, C. (2019). The effect of teaching practices on pre-service teachers' sense of efficacy belief and attitude towards teaching profession. Uluslararası Eğitim Programları Ve Öğretim Çalışmaları Dergisi, 9(1), 01-32. https://doi.org/https://doi.org/10.31704/ijocis.2019.001

Boyd, D., Lankford, H., Loeb, S., Rockoff, J., \& Wyckoff, J. (2008). The narrowing gap in New York City teacher qualifications and its implications for student achievement in high-poverty schools. Journal of Policy Analysis and Management, 27(4), 793-818.

Bryman, A. \& Cramer, Duncan. (1999). Quantitative data analysis with SPSS for Windows. USA: Routledge.

Buddin, R., \& Zamarro, G. (2009). Teacher qualifications and student achievement in urban elementary schools. Journal of Urban Economics, 66(2), 103-115.

Büyüköztürk, Ş. (2012). Sosyal bilimler için veri analizi el kitabı (Data analysis handbook for social sciences). Ankara: Pegem A.

Can, A. (2013). SPSS ile bilimsel araştırma sürecinde nicel veri analizi (Quantitative data analysis with SPSS in scientific research prosess). Ankara: Pegem Akademi Yayıncılık.

Çapa, Y., Çakıroğlu, J., \& Sarıkaya, H. (2005). The development and validation of a Turkish version of teachers' sense of efficacy scale. Education and Science, 30(137), 74-81.

Celep, C. (2009). Meslek olarak öğretmenlik (Teaching as a profession). C. Celep (Eds.) in Eğitim bilimine giriş (Introduction to educational sciece) (pp.45-74). Ankara: Anı Yayıncılık.

Comrey, A. \& Lee, H. (1992). A first course in factor analysis. Hillsdale, NJ: Erlbaum. 
Connor, C. M., Son, S. H., Hindman, A. H., \& Morrison, F. J. (2005). Teacher qualifications, classroom practices, family characteristics, and preschool experience: Complex effects on first graders' vocabulary and early reading outcomes. Journal of School Psychology, 43(4), 343-375.

Creswell, J. W. (2002). Educational research: Planning, conducting, and evaluating quantitative. NJ: Prentice Hall.

Darling-Hammond, L. and Sykes, G. (2003). Wanted, a national teacher supply policy for education: The right way to meet the "highly qualified teacher" challenge. Education Policy Analysis Archives, 11(33), $1-55$.

Davran, E. (2006). Ilköğretim kurumlarındaki öğretmenlik uygulamasının öğretmen adaylarının öğretmenlik yeterliliklerini kazanmaları üzerindeki etkisi (The Affect of the teaching applications in elementary educations on the newly candidate teachers's teaching adequacy). (Unpublished Master Thesis). Van Yüzüncü Yıl Üniversitesi, Sosyal Bilimler Enstitüsü, Van.

DeCoster, J. (1998). Overview of factor analysis. Retrieved March 16, 2019, from http://www.stathelp.com/notes.html

Diken, I. H. (2004). Öğretmen yeterlik ölçeği Türkçe uyarlaması, geçerlik ve güvernirlik çalışması (A study of the validity and reliability of the turkish version of the teacher efficacy scale). Eurasian Journal of Educational Research (EJER), 16, 102-112.

Gibson, S. \& Dembo, M. H. (1984). Teacher efficacy: A construct validation. Journal of educational psychology, 76(4), 569-582. http://dx.doi.org/10.1037/0022-0663.76.4.569

Goldhaber, D. (2006). Teacher pay reforms: The political implications of recent research. center for American progress. University of Washington and Urban Institute. Retrieved March 10, 2019 from www.americanprogress.ort/issues/2006/12/pdf/teacher_pay_report.pdf.

Green, S. B. \& Salkind, N. J. (2005). Using SPSS for windows and macintosh analyzing and understanding data. New Jersey: Pearson Prentice Hall.

Gülebağlan, C. (2003). Öğretmenlerin işleri son ana erteleme eğilimlerinin, mesleki yeterlilik algıları, mesleki deneyimleri ve branşları bakımından karşılaştırılmasına yönelik bir araştırma. (The research comparing the procrastination tendencies of teachers in terms of their professional efficacy perceptions, experiences and branch of study). (Unpublished Master Thesis). Ankara Üniversitesi, Eğitim Bilimleri Enstitüsü, Ankara.

Guskey, T. R. \& Passaro, P.D. (1994). Teacher efficacy: A study of construct dimensions. American Educational Research Journal, 31 (3), 627-643.

Güven, Z. (2020). Yabancı Dil Olarak Türkçe Öğretiminde Öğretmenlik Uygulaması Etkinliği: Örnek Olay Çalışması. Journal of Language Education and Research, 6 (2) , 393-409 . DOI: 10.31464/jlere.695807

Hooper, D., Coughlan, J., \& Mullen, M. (2008, June). Evaluating model fit: a synthesis of the structural equation modelling literature. In 7th European Conference on research methodology for business and management studies (pp. 195-200).

IIIğan, A. (2013). Öğretmenler için etkili mesleki gelişim faaliyetleri. Uşak Üniversitesi Sosyal Bilimler Dergisi, 6 (ÖYGE Özel Sayısı), 41-56.

Karasar, N. (2012). Bilimsel araştırma yöntemleri [Scientific research methods]. Ankara: Nobel Yayıncılık.

Kaya, V. H., Polat, D. \& Karamüftüoğlu, İ. Ö. (2014). Fen bilimleri öğretimine yönelik öz-yeterlik ölçeği geliştirme çabası (Development of self-efficacy scale for science education). The Journal of Academic Social Science Studies (JASSS). 28(II), 581-595. http://dx.doi.org/10.9761/JASSS2490.

Kline, P. (1994). An Easy Guide to Factor Analysis. New York: Routledge.

Levin, B. B. (2003). Case studies of teacher development: an in-depth look at how thinking about pedagogy develops over time. New Jersey: Lawrence Erlbaum Associates, Inc.

Lodico, M. G., Spaulding, D. T. and Voegtle, K. H. (2006). Methods in educational research from theory to practice. San Francisco: Jossey-Bass.

MacCallum, R. C., \& Austin, J. T. (2000). Applications of structural equation modeling in psychological research. Annual review of psychology, 51(1), 201-226.

MoNE (2006). Öğretmenlik mesleği genel yeterlilikleri. (Teaching profession general qualifications). Ankara. Retrieved Agust 12, 2019, from http://oygm.meb.gov.tr/meb_iys_dosyalar/2017_12/13161921_YYretmenlik_MesleYi_Genel_YETERLY KLERi_onaylanan.pdf

MoNE (2017). Öğretmenlik mesleği genel yeterlilikleri (Teaching profession general qualifications). Ankara. Retrieved February 5, 2020 from https://oygm.meb.gov.tr/meb_iys_dosyalar/2017_12/11115355_YYRETMENLYK_MESLEYY_GENEL_YE TERLYKLERY.pdf 
Mundfrom, D. J, Shaw, D. G. \& Lu Ke, T. (2005). Minimum sample size recommendations for conducting factor analyses. International Journal of Testing, 5(2), 159-168. doi:10.1207/s15327574ijt0502_4

Neuman, W. L. (2007). Basics of social research qualitative and quantitative approaches. USA: Pearson Education, Inc.

Newman, I. \& Benz, R. C. (1998). Qualitative-quantitative Research Methodology: Exploring the Interactive Continuum. USA: Board of Trustees.

OSYM (2013). KPSS'de uygulanacak testlerin kapsamları (Contents of the tests of Public Personnel Selection Exam). Retrieved March, 16, 2019 from, http://dokuman.osym.gov.tr/pdfdokuman/2017/KPSS/KILAVUZ13032017.pdf

Porter-Magee, K. (2004) Teacher quality, controversy, and NCLB, the clearing house. A Journal of Educational Strategies, 78(1), 26-29. doi: 10.3200/TCHS.78.1.26-29.

Rice, J. K. (2003). Teacher quality: Understanding the effectiveness of teacher attributes. Washington: Economic Policy Institute.

Schumacher, R. \& Lomax, R. (2004). A Beginner's guide to structual equation modelling. London: Lawrence Erlbaum Associates, Publishers.

Schwarzer, R., Schmitz, G. S., \& Daytner, G. T. (1999). The Teacher Self-Efficacy scale. Retrieved February 5 , 2020 from http://www.fu-berlin.de/gesund/skalen/

Scott, D. \& Morrison, M. (2007). Key ideas in educational research. London: Continuum.

Seçer, İ. (2013). SPSS ve LISREL ile pratik veri analizi: Analiz ve raporlaştırma (Practical data analysis with SPSS and LISREL). Ankara: Anı Yayıncılık.

Şeker, H., Deniz, S. \& Görgen, İ. (2005). Tezsiz yüksek lisans öğretmen adaylarının öğretmenlik yeterlikleri üzerine değerlendirmeleri. (Prospective teacher's assessment of teacher competencies). Kuram ve Uygulamada Eğitim Yönetimi, 42(42), 237-253.

Tabachnick, B. G., \& Fidell, L. S. (2007). Using multivariate statistics. Boston: Pearson/Allyn \& Bacon.

Tanaka, J. S. (1993). Multifacated conceptions of fit in structural equation models. Kenneth A. Bollen and J. Scott Long (Eds.) in Testing structural equation model. (pp. 10-39). London: SAGE Publications.

Tavşancıl, E. (2005). Tutumların ölçülmesi ve SPSS ile veri analizi (Measurement of attitudes and data analysis with SPSS) (2nd ed.). Ankara. Nobel.

Tepe, D. (2011). Okulöncesi öğretmenlerinin öz yeterlik inançlarını belirleme ölçeği geliştirme. (Development of declaratory scale for preschool teachers? self efficacy beliefs) (Unpublished Master Thesis). Mehmet Akif Ersoy Üniversitesi, Sosyal Bilimler Enstitüsü, Burdur.

Toprakçı, E. (2001) Okul Deneyimi-I Dersinin Teori ve Pratiği (the theory and practice of the school experience I course). X. Ulusal Eğitim Bilimleri Kongresi Bildirileri. Bolu: Abant Izzet Baysal Üniv. Eğitim Fakültesi Yayınları, 7-9 Haziran 2001(ss.1964-1372).(Basılı) Erisim: https://www.erdaltoprakci.com.tr/wp-content/uploads/2021/01/okul-deneyimi-1.pdf

Toprakçı, E. (2003) Okul Deneyimi-II Dersinin Teori ve Pratiği (the theory and practice of the school experience II course). Eğitim Araştırmaları Dergisi Anı Yayıncılık Ltd.Şti. Yıl:3, Kış 2003; Sayı: 10, 146152 http://ejer.com.tr/en/archives/2003-winter-issue-10 lkinci

Erisim: https://www.erdaltoprakci.com.tr/wp-content/uploads/2021/01/Okul-Deneyimi-II-Dersininejer.pdf

Toprakçı, E. ve Üstün, A. (2003) Okul Deneyimi Pratiğine Uygulama Okulu Personelinin Bakışı -Sivas ve Amasya İlleri Karşılaştırması- (View of Practice School Staff on the practice of the School Experience course -Comparison of Sivas and Amasya Provinces). Atatürk Üniversitesi Kazım Karabekir Eğitim Fakültesi Dergisi. Eğitim Bilimleri Özel Sayı. Yıl: 2003, Sayı: 7. ss:291-303. http://edergi.atauni.edu.tr/index.php/kkefd/issue/view/282/showToc Ikinci Erisim: https://www.erdaltoprakci.com.tr/wp-content/uploads/2021/01/Okul-Deneyimi-Pratigi.pdf

VanderStoep, S. W. \& Johnston, D. D. (2009). Research methods for everyday life: Blending qualitative and quantitative approaches. San Francisco: John Wiley \& Sons, Inc.

Yiğit, N. \& Alev, N. (2007) Okul Deneyimi Dersinde Özel Danışmanlık Hizmetlerinin Mesleki Gelişime Katkısının İncelenmesi Necatibey Eğitim Fakültesi Elektronik Fen ve Matematik Eğitimi Dergisi (EFMED) Cilt 1, Sayı 1, Aralık 2007, sayfa 85-101. 
APPENDIX-1

\section{Professional Qualification Scale for Pre-service Teachers}

\begin{tabular}{|c|c|c|c|c|c|c|}
\hline \# & Subject of the Qualification & & $\begin{array}{lll}\text { vel } \\
<--\end{array}$ & Que & fica & \\
\hline 1 & Making each of my students to realize that they are valuable. & 1 & 2 & 3 & 4 & 5 \\
\hline 2 & Respecting individual differences of my students. & 1 & 2 & 3 & 4 & 5 \\
\hline 3 & Considering my students' needs while supporting each of their teaching process. & 1 & 2 & 3 & 4 & 5 \\
\hline 4 & Aiming to increase each of my students' objectives (gaining) whatever their academic level is. & 1 & 2 & 3 & 4 & 5 \\
\hline 5 & Making my students from different academic levels to gain self-efficacy for success. & 1 & 2 & 3 & 4 & 5 \\
\hline 6 & Analyzing my quality about my in-class works objectively. & 1 & 2 & 3 & 4 & 5 \\
\hline 7 & Analyzing my quality about my non-class works objectively. & 1 & 2 & 3 & 4 & 5 \\
\hline 8 & Determining deficiencies of my personal development (critical thinking, problem solving, communication etc.). & 1 & 2 & 3 & 4 & 5 \\
\hline 9 & Determining deficiencies of my professional development. & 1 & 2 & 3 & 4 & 5 \\
\hline 10 & Developing appropriate measurement tools for assessing my students' objectives. & 1 & 2 & 3 & 4 & 5 \\
\hline 11 & Using different measurement methods and strategies for determining my students' objectives. & 1 & 2 & 3 & 4 & 5 \\
\hline 12 & Following my students' development regularly. & 1 & 2 & 3 & 4 & 5 \\
\hline 13 & Interpreting the results of measurements with appropriate techniques. & 1 & 2 & 3 & 4 & 5 \\
\hline 14 & Taking precautions if there exist weaknesses of my students according to measurement and assessment results. & 1 & 2 & 3 & 4 & 5 \\
\hline 15 & Reviewing my lesson plans according to measurement and assessment results. & 1 & 2 & 3 & 4 & 5 \\
\hline 16 & Reviewing activities according to measurement and assessment results. & 1 & 2 & 3 & 4 & 5 \\
\hline 17 & Analyzing the socio-cultural characteristics of my school's environment. & 1 & 2 & 3 & 4 & 5 \\
\hline 18 & Considering the socio-cultural characteristics of my school's environment in teaching process. & 1 & 2 & 3 & 4 & 5 \\
\hline 19 & $\begin{array}{l}\text { Benefiting the opportunities of school environment (cultural resources, public support, professional organization's } \\
\text { support etc.) for the development of my students. }\end{array}$ & 1 & 2 & 3 & 4 & 5 \\
\hline 20 & Organizing events for recognizing my students' parents. & 1 & 2 & 3 & 4 & 5 \\
\hline 21 & Connecting with my students parents. & 1 & 2 & 3 & 4 & 5 \\
\hline 22 & Making my students' parents have confidence in school. & 1 & 2 & 3 & 4 & 5 \\
\hline 23 & Making my students' parents contribute to teaching-leaming process. & 1 & 2 & 3 & 4 & 5 \\
\hline 24 & Organizing teaching activities appropriate with my field's principles and approaches of curriculum. & 1 & 2 & 3 & 4 & 5 \\
\hline 25 & Following the changes in my field's curriculum. & 1 & 2 & 3 & 4 & 5 \\
\hline 26 & Making suggestions for improving my field's curriculum based upon my problems I experienced in practice. & 1 & 2 & 3 & 4 & 5 \\
\hline 27 & Evaluating subjects of my field's curriculum in terms of relevance to my students all developmental characteristics. & 1 & 2 & 3 & 4 & 5 \\
\hline 28 & Selecting teaching material proper to my field's curriculum. & 1 & 2 & 3 & 4 & 5 \\
\hline
\end{tabular}




\section{Öğretmen Adayları için Mesleki Yeterlik Ölçeği²}

\author{
Doç. Dr. Pinar YENGIN SARPKAYA
}

Aydın Adnan Menderes Üniversitesi-Türkiye pinar@sarpkaya.net

\author{
Araș. Gör. Burcu ALTUN \\ Aydın Adnan Menderes Üniversitesi-Türkiye \\ burcu.altun@adu.edu.tr
}

\begin{abstract}
Özet:
Öğretmen eğitimi, eğitim sisteminin önemli bir bileşenidir ve öğretmen adaylarının öğretim becerilerini geliştirmeyi hedefler. Öğretmen adaylarının öğretim becerileri ise onların mesleki yeterlikleri ile yakından ilişkilidir. Bu çalışma, öğretmen adaylarının mesleki yeterliklerine ilişkin algılarını değerlendirmek için geçerli, güvenilir, çok boyutlu bir ölçme aracı geliştirmeyi amaçlamaktadır. Araştırma tarama modelinde tasarlanmış olup, çalışmaya 247 öğretmen adayı katılmıştır. Veri analizi için açımlayıcı ve doğrulayıcı faktör analizi yapılmıştır. Araştırma sonuçları, geliştirilen "Öğretmen Adayları için Mesleki Yeterlik Ölçeği"nin, öğretmen adaylarının yeterliklerine ilişkin algılarını ölçmede 0,94 Cronbach alfa değerine sahip geçerli, güvenilir bir araç olduğunu ortaya koymaktadır. Ölçek öğretmen niteliklerini Öğretim ve Gelişimi İzleme ve Değerlendirme, Program ve İçerik Bilgisi, Kişisel ve Mesleki Değerler, Okul-Aile İlişkileri, Mesleki Gelişim ve Okul Ortamı olmak üzere 6 boyutta inceler.
\end{abstract}

Anahtar kelimeler: Aday öğretmen, nitelik, mesleki gelişim, öz-yeterlik, ölçek.

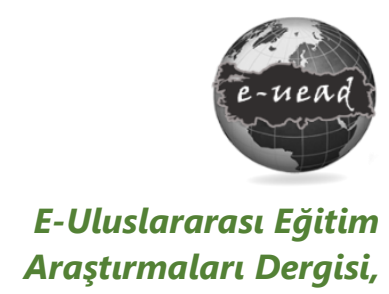

Cilt: 12, Sayt: 1, 2021, ss. 104-123

DOI: 10.19160/ijer.836733

Gönderim : 12.06.2020

Kabul : 12.02 .2021

\section{Önerilen Atıf:}

Yengin Sarpkaya, P. \& Altun, B. (2021). Professional Qualification Scale for Pre-service Teachers, E-Uluslararası Eğitim Araştırmaları Dergisi, Cilt: 12, Sayı: 1, 2021, ss. 104-123, DOI: 10.19160/ijer.836733

\footnotetext{
${ }^{2}$ Bu çalışmanın bir bölümü "International Symposium of New Issues in Teacher Education (2016)"da sözlü bildiri olarak sunulmuştur.
} 


\section{GENIŞLETILMIŞ ÖZET}

Problem durumu: Ülkelerin refahında eğitim büyük önem taşımaktadır. Özellikle, öğretmen eğitimi, eğitimin gelişimi için anahtar faktördür. Öğretmen eğitiminin amaçlarına ulaşmak için eğitim sisteminin niteliğinin değerlendirilmesi ve buna göre politikaların geliştirilmesi gerekir.

Eğitim araştırmaları, ikna edici bir şekilde, öğrenci başarısını etkileyen en önemli faktörün ögretmenin kalitesi olduğuna işaret etmektedir (Goldhaber, 2006). Eğitimin niteliği, birçok durumda ögrretmen niteliğine paralel görünmektedir (Celep, 2009).

Öğretmen niteliğinin tanımı kültürden kültüre değişebilir. Rice (2003) öğretmen niteliğini yansıtan beş özelliği (1) öğretmen deneyimi, (2) öğretmenler için hazırlık programları ve dereceleri, (3) ögrretmen sertifikasyon türü, (4) tamamlanan belirli kurslar ve (5) ögretmenlerin standart test puanları olarak özetlemektedir. Milli Eğitim Bakanlığı (2006; 2017) öğretmen niteliklerini Kişisel ve Mesleki Değerler-Mesleki Gelişim, Öğrenciyi Tanıma, Öğretme ve Öğrenme Süreci, Öğretme ve Gelişimi İleme ve Değerlendirme, Okul, Aile ve Toplum İlişkileri ve Program ve Alan Bilgisi olarak tanımlamaktadır.

Birçok araştırma çalışması, öğretmen becerilerini tanımlama ve geliştirme ihtiyacını ele almaktadır. Biriken araştırma sonuçları, öğretmen niteliğiyle ilgili kaygıların tanınmasını desteklemektedir (Darling-Hammond ve Sykes, 2003). Bu araştırma çalışmalarından bazıları ögrretmen niteliklerinin ölçülmesi ile ilgilidir. Öğretmen niteliklerini tanımlamak, geliştirmek ve değerlendirmek için araştırmacılar tarafından geliştirilen bazı ölçekler vardır. Bazı araştırma çalışmaları öğretmen adaylarının yeterliğini ele alırken, bazıları sınıf yönetimi gibi belirli bir alandaki niteliklerine işaret etmektedir. Ancak belirli alanlarda ne kadar nitelikli olduklarına dair yeterliklerini kapsamlı bir şekilde ele alan bir araştırma yoktur. Dolayısılla araştırmanın amacı, ögretmen adaylarının mesleki yeterliklerine ilişkin algılarını değerlendirmek için geçerli ve güvenilir çok boyutlu bir ölçme aracı geliştirmektir.

Yöntem: Araştırma, tarama modelinde tasarlanmıştır. Öğretmen adaylarının mesleki yeterliklerine ilişkin algılarını değerlendirmeye yönelik geçerli ve güvenilir bir ölçme aracı geliştirmek için en iyi model betimsel tarama modelidir. Araştırmanın çalışma grubu, 2015-2016 eğitim öğretim yılında Aydın Adnan Menderes Üniversitesi Eğitim Fakültesi Pedagojik Formasyon Sertifika Programına kayıtlı ögretmen adayları olarak belirlenmiştir. Küme örneklemesine dayalı olarak 53 maddelik ölçek 290 katılımcıya uygulanmıştır. Madde oluşturma süreci 53 maddelik ölçek ile sonuçlanmış, her madde sadece bir davranışı temsil eden cümle şeklinde yazılmıştır. Düşük dereceden yükseğe doğru ölçekteki her bir madde için 5 'li Likert ölçeği betimlenmiştir. Madde havuzunda ters kodlanmış madde bulunmamakta ve tamamı olumlu cümlelerden oluşmaktadır. Ölçme aracının içeriği ve görünüş geçerliliği sağlanmıştır. Bu ölçek geliştirme araştırmasında geçerli ve güvenilir bir ölçme aracı oluşturmak için açımlayıaı (AFA) ve doğrulayıaı (DFA) faktör analizi teknikleri kullanilmıştır.

Bulgular: Verilerin faktör analizi için uygun olup olmadığını belirlemeden önce Kaiser-MeyerOlkin (KMO) yeterlik değeri ve Bartlett's test sonucu kullanılmıştır. Verilerin faktör analizi için mükemmel uyum gösterdiği sonucuna varılmıştır. Faktör analizi sonucunda 28 maddelik Ögrretmen Adayları için Mesleki Yeterlik Ölçeğinin 6 boyuttan (KMO = .97; $p<.000$ ) oluştuğu belirlenmiştir: Birinci boyutta 5; ikinci boyutta 4; üçüncü boyutta 7; dördüncü boyutta 3; beşinci boyutta 4; altıncı boyutta 5 madde bulunmaktadır. 1, 2, 3, 4 ve 5. maddeler "Kişisel ve Mesleki Değerler" olarak adlandırılan 1. boyut altında toplanmıştır. 8., 9., 10. ve 11. maddeler "Mesleki Gelişim" olarak adlandırılan 2. boyut altında toplanmıştır. 31, 32, 33, 35, 36, 37 ve 38. maddeler "Öğretimi ve Gelişimi İleme ve Değerlendirme" adı verilen 3. boyut altında toplanmıştır. 39, 40 ve 41. maddeler "Okul Ortamı" adı verilen 4. boyut altında toplanmıștır. 44, 45, 46 ve 47. maddeler "Okul-Aile ilişkileri" adlı 5. boyut altında toplanmıştır. Son olarak 49, 50, 51, 52 ve 53. maddeler "Program ve Alan Bilgisi" olarak adlandırılan 6. boyut altında toplanmıştır.

Açımlayıcı faktör analizi ile sonuçlanan 6 faktörlü yapının geçerliliği, doğrulayıcı faktör analizi ile de incelenmiştir. Model uyum indekslerine göre "Öğretmen Adayları için Mesleki Yeterlik Ölçeği" yapısının geçerli olduğu sonucuna varılmıştır. Madde-faktör korelasyonları, her bir maddenin ait 
olduğu boyutla ilişkisini ve faktörün tutarlılı̆ını gösterir. Her bir madde için madde-faktör korelasyon değerleri ve faktörler arasındaki korelasyonlar hesaplanmıştır. Sonuç olarak, ölçeğin her bir maddesinin ait olduğu faktör ile anlamlı ve pozitif bir ilişkiye sahip olduğu $(p<.01)$ ve tüm faktörlerin birbiriyle ilişkili olduğu ve anlamlı bir ölçüde tüm faktörlerin aynı yapıda olduğu sonucuna varılmıştır.

Madde ayırt etmenin diğer bir ölçütü de katılımcıların \%27'sinin üst ve alt kısımlarının madde ortalamaları arasındaki toplam puanlara göre anlamlı farklılı olmasıdır. Tüm madde ortalama puanları, katılımcıların alt ve üst \% 27'si arasında anlamlı farklılık göstermektedir. Böylece ölçeğin ayırt ediciliğinin iyi olduğu sonucuna varılmıştır $(p<0.001)$.

Bu çalışmada, güvenirliği belirlemek için her faktör ve ölçeğin tamamı için Cronbach alfa katsayıları hesaplanmıştır. 28 maddelik toplam ölçeğin Cronbach alfa güvenirlik katsayısı 0,94 olup, yüksek güvenilirliği göstermektedir. Her faktör için Cronbach alfa değerleri sırasıla 0.81, $0.74,0.87,0.80,0.86$ ve 0.86 'dır. Dolayısıyla sonuçlar, ölçeğin iç tutarlıı̆ının yeterince yüksek olduğunu göstermektedir.

Sonuçlar: Elde edilen ölçeğin boyutları ve açıklamaları şu şekildedir:

- Kişisel ve Mesleki Değerler boyutu, bireyin öğrencilere değer verme, onları cesaretlendirme ve her bir öğrenciyi bireysel olarak destekleme yönünden yeterliğini 5 maddeyle (1-5) ölçer,

- Mesleki Gelişim boyutu, bireyin kendi mesleki gelişimini eleştirel olarak değerlendirme açısından yeterliğini 4 maddeyle (6-9) ölçer,

- Öğretimi ve Gelişimi izleme ve Değerlendirme boyutu, bireyin hedeflere ulaşıp ulaşmadığını takip etme ve değerlendirme açısından yeterliğini 6 maddeyle ölçer (10-16),

- Okul Ortamı boyutu, okulun faaliyet gösterdiği ortamı analiz etme ve kullanma açısından bireyin yeterliğini 3 maddeyle (17-19) ölçer,

- Okul-Aile ilişkileri boyutu, bireyin öğrenci ailesiyle iletişim kurma, işbirliği yapma ve ögrretme ve ögrenme sürecine katkı sağlamaya yönelik yeterliklerini 4 maddeyle (20-23) ölçer,

- Program ve içerik Bilgisi boyutu, bireyin kendi alanındaki programı analiz etme, buna göre harekete geçme ve öğretim etkinliklerini buna göre düzenleme açısından yeterliğini 5 maddeyle (24-28) ölçer. 


\section{EK-2}

\section{Öğretmen Adayları için Mesleki Yeterlik Ölçeği}

\begin{tabular}{|c|c|c|c|c|c|c|}
\hline \multirow{2}{*}{ \# } & \multirow{2}{*}{$\begin{array}{c}\text { Yeterlik konusu } \\
\text { Öğrencilerimin her birinin önemli olduğunu onlara fark ettime }\end{array}$} & \multicolumn{5}{|c|}{$\begin{array}{c}\text { Yeterlik düzeyiniz } \\
\text { Az }<-\cdots \text { Çok }\end{array}$} \\
\hline & & 1 & 2 & 3 & 4 & 5 \\
\hline 2 & Öğrencilerimin bireysel farklılıklarına saygı duyma & 1 & 2 & 3 & 4 & 5 \\
\hline 3 & Öğrencilerimin her birinin öğrenmesini desteklerken onlann ihtiyaçlannı göz önünde bulundurma & 1 & 2 & 3 & 4 & 5 \\
\hline 4 & Düzeyi ne olursa olsun her bir öğrencimin kazanımlarını artırmayı hedefleme & 1 & 2 & 3 & 4 & 5 \\
\hline 5 & Farkı düzeylerdeki öğrencilerimin başanlı olabileceklerine ilişkin her birine özgüven kazandırma & 1 & 2 & 3 & 4 & 5 \\
\hline 6 & Sınıf içi çalışmalarım konusunda kendi niteliğimi tarafsızca değerlendirme & 1 & 2 & 3 & 4 & 5 \\
\hline 7 & Sınıf dışı çalışmalanm konusunda kendi niteliğimi tarafsızca değerlendirme & 1 & 2 & 3 & 4 & 5 \\
\hline 8 & Kişisel gelişimimdeki eksiklikleri (Eleştirel düşünme, problem çözme, iletişim, estetik anlayış gibi) saptama & 1 & 2 & 3 & 4 & 5 \\
\hline 9 & Mesleki gelişimimdeki eksiklikleri saptama & 1 & 2 & 3 & 4 & 5 \\
\hline 10 & Öğrencilerimin kazanımlannı değerlendirmeye uygun ölçme araçlan hazırlama & 1 & 2 & 3 & 4 & 5 \\
\hline 11 & Öğrencilerimin kazanımlannı belirlemek için farklı̈ olçme yöntem ve stratejilerini uygulama & 1 & 2 & 3 & 4 & 5 \\
\hline 12 & Öğrencilerimin gelişimlerini düzenli olarak izleme & 1 & 2 & 3 & 4 & 5 \\
\hline 13 & Yaptığım ölçmelerin sonuçlannı uygun teknikler kullanarak yorumlama & 1 & 2 & 3 & 4 & 5 \\
\hline 14 & $\begin{array}{l}\text { Ölçme ve değerlendirme sonuçlarından hareketle öğrencilerimin varsa zayıf yönlerini geliştirmeye yönelik } \\
\text { önlemler alma }\end{array}$ & 1 & 2 & 3 & 4 & 5 \\
\hline 15 & Ölçme ve değerlendirme sonuçlarına göre ders planlanmda düzenleme yapma & 1 & 2 & 3 & 4 & 5 \\
\hline 16 & Ölçme ve değerlendirme sonuçlarına göre etkinliklerde düzenleme yapma & 1 & 2 & 3 & 4 & 5 \\
\hline 17 & Okulumun bulunduğu çevrenin sosyo-kültürel özelliklerini analiz etme & 1 & 2 & 3 & 4 & 5 \\
\hline 18 & Öğretim sürecinde okulumun bulunduğu çevrenin sosyo-kültürel özelliklerini dikkate alma & 1 & 2 & 3 & 4 & 5 \\
\hline 19 & $\begin{array}{l}\text { Öğrencilerimin gelişimi için okul çevresinin olanaklarından (kültürel zenginlikler, halkın ekonomik katkısı, } \\
\text { çeşitli meslek kuruluşlannın katkılan vb.) yararlanma }\end{array}$ & 1 & 2 & 3 & 4 & 5 \\
\hline 20 & Öğrencilerimin ailelerini tanımaya yönelik etkinlikler düzenleme & 1 & 2 & 3 & 4 & 5 \\
\hline 21 & Öğrencilerimin aileleri ile etkili iletişim kurma & 1 & 2 & 3 & 4 & 5 \\
\hline 22 & Öğrencilerimin ailelerinin okula güven duymalarını sağlama & 1 & 2 & 3 & 4 & 5 \\
\hline 23 & Öğrencilerimin ailelerinin öğretme-öğrenme sürecine katkıda bulunmalannı sağlama & 1 & 2 & 3 & 4 & 5 \\
\hline 24 & Branşımın / alanımın öğretim programının ilke ve yaklaşımlanna uygun öğretim etkinlikleri düzenleme & 1 & 2 & 3 & 4 & 5 \\
\hline 25 & Branşımın / alanımın öğretim prog ramında yapılan değişiklikleri izleme & 1 & 2 & 3 & 4 & 5 \\
\hline 26 & $\begin{array}{l}\text { Uygulamada yaşadığım sorunlardan hareketle, branşımın / alanımın programını iyileştirmeye yönelik } \\
\text { öneriler gelişştme }\end{array}$ & 1 & 2 & 3 & 4 & 5 \\
\hline 27 & $\begin{array}{l}\text { Branșımın / alanımın öğretim programındaki konulannı öğrencilerimin tüm gelişim özelliklerine uygunluk } \\
\text { açısından değerlendirme }\end{array}$ & 1 & 2 & 3 & 4 & 5 \\
\hline 28 & Branşımın / alanımın öğretim programına uygun öğretim materyali seçme & 1 & 2 & 3 & 4 & 5 \\
\hline
\end{tabular}

